\title{
(Re)Interpretations by Teachers of the National Geography Curriculum for Primary Education in Portugal
}

\author{
Felisbela Martins, Carlinda Leite
}

\begin{abstract}
In Portugal, the Currículo Nacional do Ensino Básico [National Curriculum for Primary Education] was published in 2001. This document reorganises primary level education from a curricular point of view. It is a key reference document for curricular management in Portuguese schools and outlines guidelines for the whole set of educational experiences as well as the core and specific skills that students are to develop in each subject or subject area.

Since the implementation of this curriculum reorganisation, working documents have been produced by the Geography Department of the Faculty of Arts of the University of Porto, reflecting the interpretation of documents issued by the Ministry of Education and providing guidelines regarding teacher training in this subject area. These documents were shared among students, future teachers and also trainee supervisors during training sessions.

Centred on issues concerning the National Curriculum for Primary Education and Curriculum Guidelines for Geography, this paper aims to present not only the reasons that led the authors of the Geography Curriculum to provide certain options, but also the (re) interpretations made by Geography teachers who graduated from the Faculty of Arts of the University of Porto as regards the fulfilment of the prescribed curriculum at national level, that is, in their professional teaching practice.
\end{abstract}

Key words: curriculum, Geography teaching, Portugal

\section{Nastavničke (re)interpretacije nacionalnog kurikuluma geografije za osnovnoškolsko obrazovanje u Portugalu}

Cúrriculo Nacional do Ensino Básico [Nacionalni kurikulum za osnovnoškolsko obrazovanje] u Portugalu objavljen je 2001. godine. Tim je dokumentom, s obzirom na kurikulum, reorganizirano obrazovanje na osnovnoškolskoj razini. On je temeljna referenca za upravljanje nastavnim planom i programom u portugalskim školama i sadržava glavne smjernice za cijeli niz obrazovnih iskustava, kao i za opće i specifične vještine koje učenici moraju razviti u svakom predmetu ili tematskom području.

Primjenom reorganizacije kurikuluma, na Geografskom odsjeku Filozofskog fakulteta Sveučilišta u Portu napravljeni su radni dokumenti kojima su definirane smjernice za obrazovanje nastavnika u ovom području u skladu s interpretacijom dokumenata izdanih od strane Ministarstvo obrazovanja. Ti su dokumenti podijeljeni studentima, budućim nastavnicima i njihovim mentorima na pripremnim radionicama.

Cilj ovog rada je, s naglaskom na pitanja koja se nameću u Nacionalnom kurikulumu za osnovnoškolsko obrazovanje i smjernicama za geografiju, predstaviti ne samo razloge zbog kojih su autori kurikuluma geografije osigurali određenu mogućnost izbora, nego i

Please cite this article as: Martins, F., Leite C., 2011: (Re)Interpretations 
(re)interpretacije koje su ponudili nastavnici geografije-diplomanti Filozofskog fakulteta Sveučilišta u Portu s obzirom na ispunjavanje zahtjeva kurikuluma na nacionalnoj razini u svojoj nastavničkoj praksi.

Ključne riječi: kurikulum, nastava geografije, Portugal

\section{INTRODUCTION}

Within the scope of Education, namely Primary Education ${ }^{1}$, Portugal implemented curriculum changes at the beginning of the new millennium. These changes stemmed from the work developed by the Ministry of Education together with the educational community. New forms of curriculum design emerged and, in terms of legal discourse, new mandates were granted to schools and teachers.

The Curriculum Reorganisation of Primary Education introduced in January 2001 established a National Curriculum for this level of education, which is organised around both general and specific skills for each subject area, presenting further suggestions for development through educational experiences to be provided to students.

Regarding the subject of Geography, Curriculum Guidelines were drawn up in line with the principles and guidelines of the National Curriculum, pointing to a significant breach in the way the curriculum is designed and the role of teachers.

During the implementation process of the National Curriculum, the Geography Department of the Faculty of Arts of the University of Porto produced papers and other working documents within the context of initial teacher training, reflecting an analysis and interpretation of the documents issued by the line ministry. Moreover, these documents aimed to help prepare future teachers who, in addition to having specialised in Geography, must now also become curriculum designers and managers. In other words, they should be able to plan curriculum situations that are suitable to the contexts that characterise the school and make up actual representations of the teaching profession.

After nearly a decade of generalisation concerning the National Curriculum, this paper questions which actions are generated in schools, in light of the (re)interpretations of this curriculum by the Geography teaching community. This paper also puts forward questions as to the (re)interpretations of the training provided during the initial teacher training for Geography teachers offered by the Faculty of Arts of the University of Porto. In other words, our questions are about how schools and Geography teachers adopt the concepts underlying the Official Documents and those produced during the initial teacher training. We question which directions and meanings are embedded at the level of teaching practices.

In this framework, it is important for us, as teachers of the Geography Department, to better understand how both the National Curriculum for Primary Education and the Curriculum Guidelines for Geography, as well as the (re)interpretations accomplished within the Geography Department's Initial Teacher Training Programme, are influencing and being interpreted in practice by teachers. 
Moreover, in order to carry out this research, interviews were conducted with the authors of the Curriculum Guidelines for Geography, aiming to perceive their conceptions and representations of the National Curriculum and Curriculum Guidelines they produced. Class diaries were also requested from 6 primary school teachers, with the intention of learning more about the practices they follow. Discourses by the authors and teachers in class diaries were analysed using the content analysis method (Bardin, 1979).

Thus, this paper also describes how the collected data was interpreted, in addition to the theoretical context of the position that guides us in the light of these issues, constituting a framework of analysis for these data. To this end, the study is divided into five sections. The first concerns a brief theoretical overview of the matter, the second briefly presents the master lines of the Portuguese National Curriculum and the Curriculum Guidelines for Geography, and the third presents directions and actions of Initial Teacher Training in Geography at the Faculty of Arts of the University of Porto. The fourth section presents the methodology used in the research and the fifth the results obtained. The paper concludes with a few brief final considerations.

\section{1 - Curriculum Reorganisation of Primary Education at the beginning of the $21^{\text {st }}$ century: from "curriculum as project" to the role of teachers as "curriculum designers".}

The Curriculum Reorganisation of Primary Education that began in this century has come to show and reiterate how important it is for the Curriculum also to be thought out by schools and the teachers who work there. In this regard, the "need to overcome the perception of the curriculum as a set of standards to be met in a supposedly uniform manner in all classrooms and to point out the development of new curriculum management practices taking into account the increasing autonomy of schools" (DL N ${ }^{\circ} 6 / 2001$, Preamble) is acknowledged. According to the legal document establishing this reorganisation, the Curriculum is understood as "the set of learning experiences and skills to be developed by students throughout primary education" (Art. 2-1) and translates as "a number of skills that are considered core and structuring (...) for each cycle". In addition to this conception, the document also highlights the existence of "disciplinary and non-disciplinary curricular areas" in view of developing significant learning experiences and integral training of students through consolidation and contextualisation of knowledge (Art. $3 \mathrm{c}$ ) and "integration with a transversal nature, from education to citizenship in all curriculum areas" (Art. $3 \mathrm{~d}$ ).

What this paper intends to show when convening the aforementioned legal document, is that it was intended, in terms of discourse, to break with the concept of curriculum understood as a set of universal national programmes in which schools are perceived as institutions that are limited to enforcing this curriculum upon students. Rather, it is assumed that schools, once elite institutions, should be a place for the training of all youngsters and, in this sense, it must be a location for recontextualising the formal national curriculum.

These ideas are in line with the thought and opinion of Zabalza (2003, p.17) on the school curriculum, who states that the curriculum is "all sorts of arrangements and processes that each society sets up so that the right of children and young people to education and personal and educational development becomes effective through the schools. Thus, 
'curriculum' herein refers to what is done at schools, that is, the response given by schools (and/or through schools) in relation the right of children and young people to education".

This implies rethinking the curriculum, which is meant to be learnt by a different society and in which student learning must include different areas of the past, albeit very recent. According to Roldão (1999, p.36), the curriculum must integrate "a range of different learning contents including reference knowledge areas without which access to knowledge cannot be put into operation". Moreover, the author goes further when she states that one must develop "activation and consolidation of autonomous knowledge building, command of tools to access knowledge in the diversity of its forms; development of social attitudes and skills; mechanisms for individual development and improvement of quality of life" (idem).

In this dimension, the curriculum is understood as a corpus that incorporates a set of measures and actions to be perceived differently by everyone. That is, the curriculum becomes a space where you can manage and make decisions, which implies new roles for schools and teachers. As stated by Zabalza (1992, p.47), "it is to understand the curriculum as an area for decision-making in which, based on the Programme and by programming, the school community, at school level, and the teacher, at class level, articulate their respective frameworks for action". However, this concept of curriculum also implies a different role for students, who are no longer mere receptors of conveyed information, but agents producing their own knowledge so as to develop skills which will enable them to live in today's ever-changing society.

According to this concept of curriculum, schools must be a place for decision-making and teachers working in these schools ought to be able to manage and decide what to teach, how to teach, why and what for, and also to facilitate learning, that is, the curriculum should not be perceived "merely as a set of subjects to be taught in pre-made information packages, or even as a set of highly structured school programmes that allow students to develop the required skills, but rather as a set of intentions, means and activities that allow students to actively participate in building their own knowledge and developing themselves in a positive way, both social and socially" (Leite 2000, p.21). It is within the scope of such perspectives that the idea of curriculum as project emerges, which implies "establishing relationships between different actors and interests and between different knowledge areas. It implies finding a direction for what you want and what you do and developing processes that make learning meaningful. It implies thinking of education in a social dimension and the school as a mandate that is not confined to instruction, but includes training which generates real education" (Leite 2000,p.22).

The novelty in this curricular reorganisation was the challenge for the school or group of schools to draw up their project, with the aim of improving the level and quality of student learning, taking on a number of options and learning priorities. This attitude by the school, according to Leite (2003, pp.124-125), makes it a "curricularly intelligent school", that is, an "institution which, instead of merely managing and distributing knowledge, following a logic of linear and convergent thinking, promotes practices through which creativity and skills of a cognitive, affective and social nature are developed".

Within this new framework, in which a curriculum as project is preferred, enabling design according to diversity and local realities, as well as different social contexts, 
teachers must play a role that includes not only having a good command of knowledge of what they teach, but also understanding what they teach for. It is therefore important also to break with reproducing situations and that teachers be "curriculum designers" (Leite 2003, p.131). This role as curriculum designers assumes that teachers play a role in the management of curriculum development processes and are mediators between the proposals comprised in the National Curriculum and students' achievement of the learning required. The transition from formal curriculum to actual curriculum is a process carried out by teachers, who intervene as curriculum development agents.

\section{2 - The National Curriculum for Geography and the Curriculum Guidelines for the $3^{\text {rd }}$ Cycle of Primary Education.}

The National Curriculum for Primary Education established by Decree-Law No. $6 / 2001$ of January $18^{\text {th }}$, herein mentioned, is understood as a set of skills considered as core, general and specific and a number of learning experiences that ought to be provided to students. The notion of skill is understood as "the process of activating resources (knowledge, abilities and strategies) in different types of situations, including problem situations, (...) is a broad concept in which knowledge, abilities and attitudes are integrated, better mobilised (...), or in action or in use" (ME-DES, p. 9).

This concept is in the same line of thought as Perrenoud's $(1999$, p. 7$)$, who argues that skill is "an ability to act efficiently in a particular type of situation based on, but not limited to, knowledge".

As regards the subject of Geography, there was a concern to formulate specific skills for Geography according to "an integrating perspective of attitudes, abilities and knowledge to be developed by students through geographical education" (ME-DES, 2001, p.107), with the purpose of students becoming geographically competent young citizens. According to the Primary Education Department in Portugal, "the geographically competent citizen is one who has a good command of spatial skills and shows that s/he is capable of visualising facts in spatial terms and relating them, of correctly describing the environment $\mathrm{s} /$ he lives or works in, of drawing up a mental map of that environment, of using several different scale maps, of understanding spatial patterns and comparing them, of possessing a good sense of terrestrial orientation" (idem). In addition to these spatial skills, a geographically competent citizen is also one who (ibidem) "is capable of interpreting and analysing geographical information and understanding the relation between territorial and cultural identity, heritage and regional individuality".

The Curriculum Guidelines for Geography further provides guiding principles to indicate actions to be carried out by teachers so that young people attending Primary School become geographically competent citizens. As such, throughout the teachinglearning process, teachers are expected to promote educational experiences with a view to the development of research-related skills. Moreover, in this sense, teachers carry the mission of developing experiences so that students shall have the opportunity to learn to observe, record, process information, formulate hypotheses, and draw conclusions and present results. Geography skills should be developed both through fieldwork and group work, which favours the promotion of ideas and the production of findings. Citing once again the line ministry (ME-DEB 2001, p.109), "through geography education, students 
learn to respond to a set of questions, such as: Where is it located? Why is it located there? How is it distributed? What are the characteristics? What is its impact? How should it be managed for the mutual benefit of mankind and the environment? [and the] search for answers to geography questions implies research on location, situation, interaction, spatial distribution and differentiation of phenomena on the Earth's surface". Furthermore, the official documents determine that skills are to be grouped in three areas: Localisation, Knowledge of Areas and Regions, and Dynamics of Interrelations among Spaces.

These three areas contribute to the development of general skills in primary education by means of 21 specific skills and the several different learning experiences proposed. In the case of Geography, skills are to be developed throughout the three cycles of Primary Education ${ }^{2}$. Geography teachers must therefore organise the teaching-learning process however they consider most appropriate to their school and class, providing opportunities for students to carry out activities that enable them to develop the know-how to contemplate space and the ability to act in the environment in which they live - a skill to be developed at the end of Primary Education.

Living in a multidimensional space, by studying a variety of contexts, young students cannot be subject to Geography teaching that is limited to memorising and localising isolated geographical concepts and facts. The Curriculum Guidelines state that core skills in Geography "are defined so as to focus learning through information search, observation, formulation of hypotheses, decision-making, development of critical attitudes, individual and group work and completion of projects" (idem). It also states that these learning experiences should be provided in teaching-learning situations about the study of landscapes, maps, fieldwork, project work and case studies.

Moreover, following from this structure, assuming that as young students develop physically, emotionally and intellectually, they also evolve in their ability to understand the World, the Ministry of Education proposes that during the $3^{\text {rd }}$ cycle of primary studies, particularly in the field of Geography, students' curiosity to discover the World should be stimulated and they should be provided with the opportunity to explore new locations and spaces on the face of the Earth. Hence, the subject should therefore be developed around an organisational theme "Towards the Discovery of Portugal, Europe and the World", around which the six major thematic areas established in the Curriculum Guidelines for Geography gravitate (Fig. 1). These topics "can be studied separately or in an integrated manner. Their distribution over the three years of the $3^{\text {rd }}$ cycle of primary education must be coordinated with the School and Class Curriculum Projects, without ever disregarding a logic of the cycle. Regarding "Earth Representations", given the nature of its content, this topic should be studied in the first place" (ibidem, 9).

The document also emphasises that (ibidem) "curriculum management should focus more on the interpretative aspects of the several different educational experiences rather than on the descriptive aspects of the syllabus".

These topics must be approached based on a scale of analysis in order to highlight the geographical phenomena under study and the most suitable to them. They should also refer to the reality in Portugal so that, by the time students complete their primary education studies, they are aware of the geography of their country. Nevertheless, this reality must 


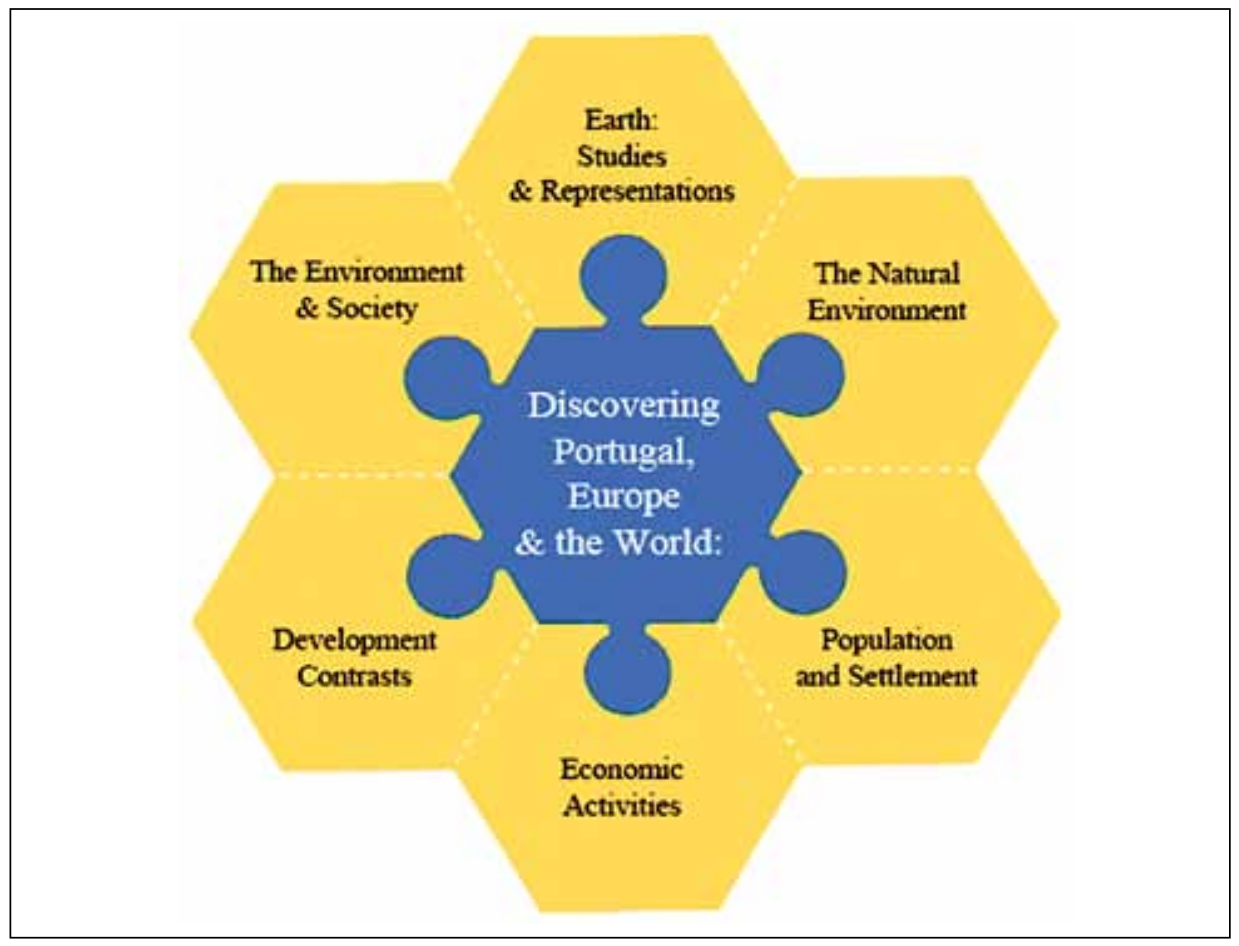

Fig. 1 Six thematic areas of the subject of Geography in the $3^{\text {rd }}$ cycle of Primary Education. Source: ME-DEB Sl. 1. Šest tematskih područja predmeta geografija u 3. ciklusu osnovnoškolskog obrazovanja. Izvor: ME-DEB

be compared with another similar and/or contrastive reality according to the phenomena under study and based on the analysis at local, continental and global scale.

The overriding aim, as stated, is that young students recognise that "physical and human factors are interrelated in a dynamic way, resulting in different spatial repercussions" (ibidem, 10).

The Curriculum Guidelines also suggest which methodology to use, emphasising case studies and situations based on real examples, at local, regional or national level, with Portugal as reference and two countries that make up relevant similar and/or contrastive examples selected from a list of one of the selected sets ${ }^{3}$. The global scale must be used mainly in the study of phenomena comprehensible only at planetary scale, such as large mountain ranges, great rivers, worldwide climate distribution, vegetation and population.

In these documents, the Ministry of Education states however that "the educational experiences proposed for each thematic area are not compulsory; they are examples of how core skills can be developed according to the means/resources and possibilities of each school. It is not mandatory to carry them out and the teacher can also select other topics considered more appropriate to curriculum development" (ibidem).

Fieldwork, group work integrating document research, information processing and presentation of conclusions are to be performed at least once each year; field trips, 
simulations, games and case studies are recommended experiences to be worked out in Geography classes.

In addition to the above, there was also a concern within the methodology framework for teaching this science to design a National Curriculum through a set of open topics, which can be managed locally in the context of each school and each class. These topics are presented so as to allow teachers, according to the specific local circumstances, to interpret them and design the curriculum of this subject from a local point of view. Hence, the Curriculum Guidelines coordinate with the directives of Flexible Management of a National Curriculum, which were also intended to be worked out locally, contributing to what is prescribed nationally being understood as a project. Appealing to the teaching methodology for this subject, based on case studies and by developing the teaching-learning process at different scales of analysis - local, regional, global - what is intended is to draw up a local curriculum that, through necessarily different paths, embodies the principle of a school that is meant for everyone.

\section{3 - The Process of Interpreting the National Curriculum by the Geography Depar- tment at the Faculty of Arts of the University of Porto}

When the National Curriculum for Primary Education entered into force in 2001, it took effect as from the $2002-2003$ academic year for the $7^{\text {th }}$ grade, and in subsequent years for the $8^{\text {th }}$ and $9^{\text {th }}$ grades.

Taking into account this way of approaching the National Curriculum, the members of the Geography Department at FLUP, associated to initial teacher training, were concerned with proceeding with its analysis, interpretation and development.

This work was developed together with students taking subjects of Geography Teaching Methodologies and specific Didactics, as well as with Trainee Supervisors. Meetings and training sessions were held with the latter. Preference was given to familiarity and the relevance and specificity of geography education, with curriculum management, teaching methods and even of learning assessment. This analysis was centred on the Curriculum Guidelines for Geography. Proposals were presented for teaching guides, yearly lesson plans and Didactic Units organised around educational situations with the purpose of contributing to an integrated management of the curriculum guidelines. Changes were proposed to the specific skills in Geography, in view of functional simplification.

In light of curriculum flexibility, we tried to break away from the classic logic of mere sequencing of ways to organise and manage the curriculum. The approach adopted was to focus the work on developing a curriculum that was intended to generate skills development. As stated by Ramalho (2005, p. 423), "we design, reflect, redesign, apply and rethink the whole process in an endless spiral" together with students. The aim was to contribute to the preparation of future teachers who, besides being experts in Geography, must also be curriculum designers, as stated previously. Furthermore, the purpose was to train teachers who possessed knowledge that would enable them to draw up curriculum situations appropriate to the contexts which characterised the school and build real views of the teaching profession. 


\section{4 - Research methodology}

As mentioned previously in the introduction to this paper, insofar as the National Geography Curriculum has been implemented for some years now and diffused throughout the country, it seems important to produce knowledge and to disclose the extent to which the National Curriculum, the Curriculum Guidelines for Geography and the interpretations made at FLUP have been taking shape.

In this sense, this study aims to give voice to the authors of the Curriculum Guidelines for Geography and to the teachers who are currently experiencing this curriculum in schools. To that end, semi-structured interviews were carried out with the authors, since the purpose was to find out about the opinions of these curriculum designers regarding the potentials and limitations they assign to the work developed, and to underline their expectations concerning its fulfilment and the pedagogical work methods developed by teachers in their practice. Semi-structured interviews were used because they can provide general information and new entries on specific topics and, therefore, allow for an understanding of the points of view of the interviewees.

In order to highlight the practices that are being experienced in schools by Geography teachers, six alumni and former trainee supervisors were invited to write three class diaries each, corresponding to three consecutive lessons (one per week), for a teaching unit. A preliminary meeting was held with these teachers so as to explain what a class diary consisted of, as well as to identify and select the Teaching Unit. The unit fell under the subtopic "Mobility" within "Population and Settlement", usually taught in the $8^{\text {th }}$ grade. After the meeting, an electronic file was delivered to teachers in order for them to draw up the class diaries, facilitating the writing and the subsequent collection of information. All teachers joined this research study and 18 class diaries were collected - as many as initially estimated.

In each diary, the teachers would have to list their activities at the level of planning and teaching each lesson, following the line of thought of Zabalza (2004, p. 13) when he says that diaries "are documents in which teachers write down their impressions about what is happening in their classrooms" and because "diaries can be used more strictly for research purposes (as a resource designed to boost the knowledge available in the educational field)" (idem, p. 16).

The information obtained from interviews and class diaries was treated by means of content analysis, which enabled handling the copious and extensive information and testimonies in a methodical manner following certain rules, as well as extracting comprehensive data other than previously expressed. In other words, this research study applied a qualitative analysis, since the purpose was to interpret the opinions of the authors of the Curriculum Guidelines and teachers' real situations in their practices. Following what is defined for content analysis, categories were set up that enabled us to grasp the apprehension of meaning of the discourses. The aim was to bring out the meanings of the material itself, based on the empirical data for the classification that best suits the objectives that justify this research procedure, seeking to understand how the authors designed the Curriculum and the Curriculum Guidelines for Geography and how teachers (re)interpret them. 


\section{5 - Results}

On initiating the interpretation of data regarding the voices of the authors of the Curriculum Guidelines for Geography, it became clear to us that for these authors the potential of this National Curriculum lies in the freedom given to teachers in managing the curriculum according to the context in which they are found, giving them autonomy to become the designers according to local realities and the students for whom it is intended. One of the authors said "It has soul. To me it does. I think it has soul". For these authors, it is the teacher's responsibility to organise the teaching-learning process, however they consider most appropriate to the context of their school and class(es).

In addition to these potentials, the authors think that this curriculum has its limitations, pointing out the fact that we have gone from a closed and prescriptive model to a more open curriculum. However, they also share the opinion that these limitations of the National Curriculum for Geography were boosted by the fact that the Ministry of Education did not carry on with the ideas initially planned, which consisted in developing processes to support teachers. The successive and subsequent government changes contributed to this situation, and, in their absence, school manuals ended up doing the job of supporting teachers, with no real breaks with the past and according to a curriculum design of the past. Still, in the view of the interviewees, teachers prefer guideline documents and do not want to manage the curriculum.

On drawing up the Curriculum Guidelines, the authors claim to have had huge expectations about how the teachers would receive them. They consulted professional associations and teachers, and the feedback was very positive on the part of primary school teachers, Faculty teachers and also teachers attending international conferences in the Iberian Peninsula. Today however, the authors have the perception that routines have been settled into in schools and that most teachers continue to follow the programme in a prescriptive manner, largely by using the school manual. The respondents also think that the manuals continue to be the resource at the service of teachers, who end up not managing the curriculum or making the adaptation to local realities and the students with whom they work. There is, therefore, no curriculum design for Geography towards the formation of citizens with the ability to understand the dynamism of spheres of knowledge and among geographical spheres of knowledge.

To answer the question "what directions and meanings are incorporated by teachers at the level of the curriculum practices they design and develop?", we enlisted, as previously mentioned, six teachers who drew up 3 class diaries between December 2009 and May 2010. A total of 18 class diaries were analysed and interpreted with regard to the organisation, management and teaching of 18 Geography classes.

In relation to the organisation and management of curriculum development, it seems evident that there are teachers who predominantly organise the teaching-learning process by designing strategies and resources conducive to student participation according to a behaviourist/technicist orientation, and there are teachers who organise it by designing strategies and resources conducive to the promotion of participation following an orientation that seeks students' emancipation and free initiative.

In the first case, the teachers plan and organise lessons based on the school manuals and workbooks, resorting to correction of homework and lessons in notebooks as well 
as revision of subjects taught in previous lessons. Based on the records, one can assume vertical dialogue is characteristic of the communication between teachers and students, since teachers expect to resort to procedures that are based on explanations, problem solving and summary schemes for the consolidation of knowledge.

In the second case, we identified a teacher who plans lessons based on the students' own experiences and identifies strategies for simulation and role-playing, which encourage a more active involvement of students in class.

As for classes, teachers who predominantly organise the teaching-learning processes by designing strategies and resources conducive to student participation according to a technicist orientation, direct the action using the provided resources and strategies and resorting to vertical dialogue. In the case of the teacher who designs strategies and resources conducive to student participation according to an orientation that seeks emancipation, s/ he eventually engages students in research activities and uses their previous conceptions and representations related to the subjects to be learned anew.

Based on the results obtained, a few inferences can be made. The first has to do with the concern of teachers putting into perspective an education in which they take on the role of organisers of learning situations. Considering this role, the teachers involved in this study underline a conception of education associated with transfer of knowledge through vertical dialogue, focussing on contents of the Geography subject without ever referring to procedural and attitudinal contents. They strictly discriminate thematic contents, the resources used and the activities developed, never addressing the assessment of the process or the results generated by education. When organising the teaching-learning process and teaching, the geographical and general skills to be developed by students were never mentioned. Occasionally however, they prepare and develop didactic moments in the classroom in order to develop the research procedure. Nonetheless, in most classes, it is the teacher who directs the action while the students play a less active role, more oriented towards the reception and understanding of what is being taught.

\section{CONCLUSIONS}

As the National Curriculum and the Curriculum Guidelines for Geography were designed in a more open rather than prescriptive model, the development of noticeable dynamics regarding a curriculum design that considers that which is prescribed at national level is a project that needs to undergo a significant curriculum redesign at local level, so as to adapt to the characteristics of the context and students who experience it. Teachers were not supposed to make a (re)interpretation of the National Curriculum and Curriculum Guidelines focused on the acquisition of knowledge, but instead on skills development. However, this does not seem to be very clear. Based on the analysis of data from the class diaries, one can see that there is a predominant concern for exclusively working out thematic contents, leaving aside the design of educational situations that may favour the development of procedures and attitudes that can also mobilise knowledge, thus creating opportunities to develop geographical skills. The concern for working out this type of content is enhanced with the use of contents comprised in school manuals. Hence, it seems that the teachers involved in this study developed a less active role in 
curriculum management than expected, by not adapting the curriculum to local realities and not making use of the autonomy that was given to them in the National Curriculum. Thus, practices related to transfer of knowledge apparently still predominate, a situation that deviates from a student-centred teaching practice and compromises the construction of their own learning processes.

Although the authors of the Curriculum Guidelines for Geography designed a Geography curriculum with the purpose of providing space to teachers so that they could also design the curriculum in accordance with local realities, and despite their high expectations with regard to its implementation, the limitations pointed out now appear to be enhanced with the curriculum practices studied among the teachers who agreed to draw up the class diaries as requested.

Thus, it is possible to infer that, at least with these teachers, the concept of curriculum as project, the teacher's role as mediator between the curriculum designed at national level and the curriculum as actually experienced locally, are not being totally appropriated and the National Curriculum and Curriculum Guidelines for Geography are largely being (re) interpreted as a normative curriculum to be followed supposedly in a similar manner in Geography classes, regardless of the context. The Curriculum Guidelines for Geography are not being (re)interpreted by teachers in the direction to form students capable of visualising facts in spatial terms and relating them, of correctly describing the environment $\mathrm{s} /$ he lives or works in, of drawing up a mental map of that environment, of using several different scale maps, of understanding spatial patterns and comparing them, or of possessing a good sense of terrestrial orientation. In their daily practices, teachers are not reinterpreting the curriculum guidelines with a view to endowing their students with spatial skills, or the ability to interpret and analyse geographical information and to understand the relation between territorial and cultural identity, heritage and regional individuality. Indeed, teachers continue to pursue modes of pedagogical work that does not lead to the development of these competences. As this study aims to analyse the extent to which the curriculum designs laid down by educational policies at the beginning of this century are being implemented, one can conclude that there is still a décalage between discourse and experience, a situation that highlights the need to develop the study of situations producing more generalisable knowledge and capable of indicating paths of intervention.

\section{NOTES}

1 The Portuguese Education System is constituted by 3 sequential levels: Primary Education, Secondary Education and Higher Education. Primary Education is developed over 9 years and organised into three sequential cycles without specific nominal designations but numbered as follows: 1st, 2nd and 3rd cycles. The first cycle has a duration of four years, the second cycle comprises two years and the length of the third is three years. The core objective of Primary Education is to ensure a universal education to the Portuguese population in general.

2 Geography is an individual subject only in the third cycle of Primary Education, as part of the Social Sciences area together with History. In the 1 st and 2 nd cycles, the subject is not autonomous. In the first cycle, it falls within Environmental Studies and, in the $2^{\text {nd }}$, it is taught in the subject of History and Geography of Portugal. 
(Re)Interpretations by Teachers of the National Geography Curriculum for Primary Education in Portugal

3 Set A - Portugal; Set B - South America, Central America, Africa and Asia (except Japan) and Set C - North America, Europe, Australia and New Zealand, Japan and the Russian Federation.

\section{REFERENCES}

Bardin, L., 1979: Análise de conteúdo, Lisboa, Edições 70. Persona.

Decreto -Lei 6/2001 de 18 de Janeiro.

Leite, C., 2000: A flexibilização curricular na construção de uma escola mais democrática e mais inclusiva. Território Educativo, 7, 20-26.

Leite, C., 2003: Para uma escola curricularmente inteligente, Porto, Edições ASA.

Ministério da Educação, 2001: Currículo Nacional do Ensino Básico: Competências essenciais, Lisboa, DEB.

Ministério da Educação, 2002: Geografia. Orientações Curriculares - $3^{\circ}$ ciclo, Lisboa, DEB.

Perrenoud, P.,1999: Porquê construir competências a partir da escola? Desenvolvimento da autonomia e luta contra as desigualdade,. Porto, ASA Editores, Cadernos do CRIAP, $\mathrm{n}^{\circ} 28$.

Ramalho, M. H., 2007: "A Geografia no $3^{\circ}$ ciclo do ensino básico e as possibilidades de rentabilização do conceito de "paisagem", in Revista da Faculdade de Letras. Geografia. Universidade do Porto, II Série. Volume I, 57- 85.

Roldão, M.C., 1999: Gestão Curricular. Fundamentos e Práticas, Lisboa, Ministério da Educação, Departamento do Ensino Básico.

Zabalza, M., 1992: Planificação e Desenvolvimento Curricular na Escola, Porto, Edições ASA, Colecções Perspectivas Actuais.

Zabalza, M., 2003: "A construção do Currículo: a diversidade numa escola para todos" in Sousa, Ó. e Ricardo, M. M., Uma Escola com sentido: o Currículo em análise e debate. Contextos, questões e perspectivas, Lisboa, Edições Universitárias Lusófonas.

Zabalza, M., 2004: Diários de aula. Um instrumento de pesquisa e desenvolvimento profissional, Porto Alegre, ARTMED.

Received (Primljeno): $2010-12-31$

Accepted (Prihvaćeno): 2011 - 03 - 20

\section{Felisbela Martins,}

Lecturer at the Geography Department of the Faculty of Arts of the University of Porto and PhD student at the Faculty of Psychology and Educational Sciences of the University of Porto

\section{Carlinda Leite,}

Full Professor at the Faculty of Psychology and Educational Sciences of the University of Porto/PhD Supervisor 
